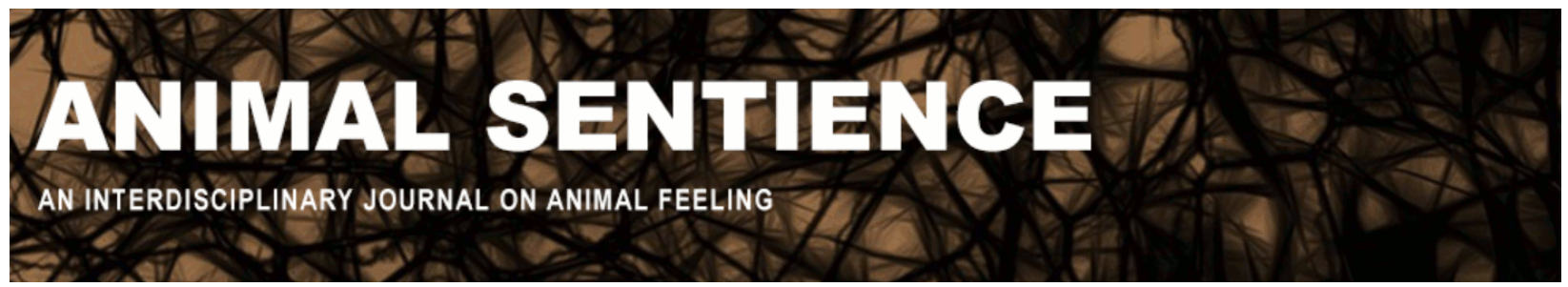

Stauffer, Jay R., Jr. (2017) Similar anatomy does not imply comparable function. Animal Sentience 13(14)

DOI: $10.51291 / 2377-7478.1275$

Date of submission: 2017-12-12

Date of acceptance: 2017-12-14 (c) $\underset{\mathrm{EY}}{\mathrm{C}}$ 


\title{
Similar anatomy does not imply comparable function
}

Commentary on Woodruff on Fish Feel

\author{
Jay R. Stauffer, Jr. \\ Ecosystem Science and Management \\ Penn State University
}

\begin{abstract}
Woodruff concludes that ray-finned fishes (Actinopterygii) are sentient and that the pallium contributes to sentience in these fishes. He gives a detailed description of the pallium; however, he assumes that similar structures in fishes and tetrapods support similar behaviors, capabilities, and functions. I reject the premise that similarities in structure imply similarities in function. The fact that a selected species of fish may exhibit behaviors, reactions, and/or anatomy suggestive of sentience does not necessarily generalize to all teleosts.
\end{abstract}

Jay R. Stauffer, Jr., Distinguished Professor of Ichthyology, Penn State University Honorary Research Associate, South African Institute for Aquatic Biodiversity, Grahamstown, SA, does research on endangered fishes, the systematics, zoogeography and behavior of freshwater fish, and the impact of introduced fishes.

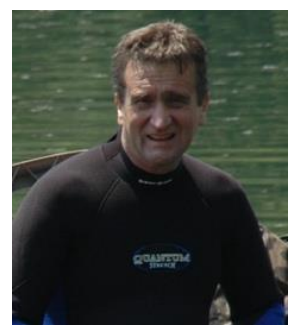

http://ecosystems.psu.edu/directory/vc5

Woodruff (2017) defends two theses in his target article. First, he concludes that ray-finned fishes (Actinopterygii) are sentient, and second, that the pallium contributes to sentience in these fishes. He rejects the argument that "... fishes lack the neuroanatomical substrates necessary for consciousness" (p. 2). To support this, he argues that the pallium found in fishes has reciprocal connections, which provide sensory input. He concludes that there is sufficient complexity to support sentience. He proceeds by discussing the neurophysiology of the pallium.

Throughout this discussion, Woodruff makes many references to tetrapods and cites many papers to support his thesis. One of the problems with this work is that it uses different definitions of sentience and cognition (see Duncan 1996, 2006; Chandroo et al. 2004; Shettleworth 2001); thus, Woodruff rejects the statement of a given author who concludes that fishes are not sentient, but bases this rejection on a different definition of sentience.

For example, Rose (2002) defines two types of consciousness. Higher order consciousness is an "awareness of one's self as an entity that exists separately from other entities" (p. 4). Rose further states that fishes are capable of associative learning and preference/avoidance of certain stimuli. Such learning does not support a capacity for consciousness. Although Woodruff makes some compelling arguments that certain behaviors of fishes support sentience, he ignores the fact that responses of fishes to noxious stimuli have been observed even after the removal of the cerebral hemispheres (Rose 2002). 
Woodruff (2017) further argues that selective attention is a "legitimate criterion for the presence of sentience" (p. 5). Johnston \& Dark (1986) recognize internal selective attention, involving memory and knowledge, and external selective attention, which includes environmental objects and events. Again, Woodruff does not define his terms. Fishes certainly show preference and/or avoid certain conditions (e.g., thermal gradients - Stauffer et al. 1976), while experiencing many other external inputs (e.g., light, current, substrate). I doubt if this selective attention to external inputs can be a criterion for sentience.

In Woodruff's evaluation of the pallial anatomy, he concludes that "teleosts have the neuroanatomical complexity necessary to contribute to sentience" (p. 9). He compares this complexity to that of mammals and assumes that structure equals function, which is not always true. For example, that fishes produce the enzyme lactase (Gawlicka et al. 1995) does not mean that they feed on milk. He continues by stating that because fishes exhibit generalized electrophysiological responses that are correlated with criteria of sentience in mammals, this further supports sentience in teleosts. Throughout the article, Woodruff supposes that since fish have structures and behaviors similar to those found in mammals, they must be sentient. In my view, that fishes can remember does not mean that they are sentient.

In conclusion, I do not deny that fishes may exhibit certain behaviors that may be construed as sentient (i.e., the social learning of species of archer fish, Toxotidae, Schuster et al. 2006). I do, however, reject the premise that similarities in structure imply similarities in function. Finally, the fact that some species of fish may exhibit behaviors, reactions, and/or anatomy that suggest sentience does not necessarily apply to all teleosts.

\section{References}

Chandroo, K. P., I. J. H. Duncan, and R. D. Moccia. (2004). Can fish suffer?: Perspectives on sentience, pain, fear and stress. Applied Animal Behaviour Science 86:225-250.

Duncan, I. J. H. (1996). Animal welfare defined in terms of feelings. Acta Agriculturae Scandinavica, Section A - Animal Science 27:29-35.

Duncan, I. J. H. (2006). The changing concept of animal sentience. Applied Animal Behaviour Science 100:11-19.

Gawlicka, A., S. J. The, S. S. O. Hung, D. E. Hinton, and J. de al Noüe. (1995). Histological and histochemical changes in the digestive tract of white sturgeon larvae during ontogeny. Fish Histology and Biochemistry 14:356-371.

Johnston, W. A. and V. J. Dark. (1986). Selective attention. Annual Reviews in Psychology 37:43-75.

Rose, J. D. (2002). The neurobehavioral nature of fishes and the question of awareness and pain. Reviews in Fisheries Science 10:1-38.

Schuster, S., S. Wöhl, M. Griebsch, and I. Klostermeier. (2006). Animal cognition: How archer fish learn to down rapidly moving targets. Current Biology 16:378-383.

Shettleworth, S. J. (2001). Review - Animal cognition and animal behavior. Animal Behavior 61:277286.

Stauffer, J. R., Jr., K. L. Dickson, J. Cairns, Jr., and D. S. Cherry. (1976). The potential and realized influences of temperature on the distribution of fishes in the New River, Glen Lyn, Virginia. Wildlife Monographs 50:1-40.

Woodruff, M. L. (2017). Consciousness in teleosts: There is something it feels like to be a fish. Animal Sentience 13(1). 